\title{
FEMINITIVES IN THE UKRAINIAN LANGUAGE: THE LINGUISTIC AND SOCIAL CONTEXT
}

\author{
Stezhko Yurii \\ $\mathrm{PhD}$ in Pedagogical Sciences, Associate Professor \\ ORCID ID 0000-0002-0226-8081 \\ National Aviation University, \\ 1, Cosmonaut Komarov Str., Kyiv, 03058, Ukraine \\ istezhko@ukr.net
}

The article highlights the problems of new spelling, in particular, the introduction of feminitives, in social and linguistic aspects. The idea is made that the feminitivization of language is a natural consequence of the Ukrainization of all spheres of social life. The relevance of the topic of our research is due to the incompleteness of linguo-social reflection regarding the assessment and boundaries of the use of feminitives. Therefore, the purpose of the article is to research the feminitization of the Ukrainian language in the linguistic and social aspects, the conditionality of the applied form of feminitives by the phonosemantic context and articulatory performance. A retrospection of spelling developments by Ukrainian linguists is carried out in the projection on the modern update of Ukrainian spelling. The social aspect of the introduction of feminitives is revealed as a manifestation of national identity and gender equality. In the linguistic aspect, the feminitivization of the language is the ordering of morphological and syntactic norms of the Ukrainian language, violated by masculinitives (designation of the female sex by male names). It is noted that the formation of feminitives using this or that suffix has a phonosemantic and contextual conditionality. In addition, an indication of the expediency / inexpediency of using one or another suffix when creating a feminitive should be the compatibility of the sounding of adjacent words, their articulatory performance and tolerance in relation to public opinion. In general, the introduction of feminitives, like the new spelling, is assessed as an adequate response to modern public demands.

Key words: culture, feminitives, masculinitives, gender policy, national identity.

\section{ФЕМІНІТИВИ В УКРАЇНСЬКІЙ МОВІ: ЛІНГВОСОЦІАЛЬНИЙ КОНТЕКСТ}

\section{Стежко Юрій}

Кандидат педагогічних наук, доцент

ORCID ID 0000-0002-0226-8081

Національний авіаційний університет

просп. Космонавта Комарова, 1, м. Київ, 03058, Україна

istezhko@ukr.net

У статті висвітлюється проблемність запровадження нового правопису, зокрема, фемінітивів у соціальному та лінгвістичному аспектах. Проводиться думка, щзо фемінітивізація мови є закономірним наслідком українізації усіх сфер суспільного буття. Актуальність теми нашої розвідки обумовлена незавершеністю лінгвосоціальної рефлексії щуодо оцінки та меж застосування фемінітивів. Відтак за мету нашої розвідки маємо висвітлення фемінітивізіції украӥнської мови у мовнокультурному та соиіальномі вимірах, обумовленість ужиткової форми фемінітивів фоносемантичним контекстом, суголоссям та артикуляційним виконанням. Здійснюється ретроспекція напрацюваннь правопису українськими

(C) Stezhko Yu., 2020 
лінгвістами у заломленні на сучасне оновлення украӥнського правопису. Соціальний аспект запровадження фемінітивів розкривається як прояв національної ідентифікації та гендерної рівності. В лінгвістичному аспекті фемінітивізація мови становить впорядкування порушених маскулінітивами (позначення жіночої статі чоловічим найменуванням) морфолого-синтаксичних норм украӥнської мови. Зазначається, шуо утворення фемінітивів за допомогою того чи іншого суфіксу має фоносемантичну та контекстуальну обумовленість. Поза тим приписом щзодо доиільності/недоиільності застосування того чи іншого суфіксу задля утворення фемінітиву мають стати фонетична сполучуваність суміжних слів, їх артикуляційне виконання у мовленнєвому процесі та толерантність стосовно суспільної думки. Назагал запровадження фемінітивів, як і нового правопису, оцінюється адекватною відповіддю на новочасні суспільні запити.

Ключові слова: культура, фемінітиви, маскулінітиви, гендерна політика, національна ідентичність.

Для одного народу - одна мова й один правопис

I. Огієнко

\section{Вступ}

Українство вступило у нову добу своєї національної ідентифікації, і одним із визначальних її чинників наразі стало просування по шляху відродження невиправдано забутого українського правопису, повернення до автентичності мови, зокрема, до ужитку фемінітивів. Першим рядком українського правопису, схваленого постановою № 437 від 22 травня 2019 р., зазначається: «Мова - запорука тривкої ідентичності нації, основа її етнокультурної цілісності» (УП, 2019). На цьому тлі доречно нагадати крилатий вислів: «Мова є живим організмом». У цих двох меседжах віддзеркалюється об'єктивна обумовленість, уся масштабність зрушень, які наразі відбулися в українському мовно-культурному просторі та потребують свого осмислення.

\section{Обговорення}

Початок XXI століття позначився на мовному ландшафті України збігом двох впливів, - 3 одного боку, постмодерністської культури, 3 іншого - політики національної ідентифікації, у якій відродження української мови посідає чи не найвагоміше місце. Проте, якщо лексика українських постмодерністів (яка інколи $\epsilon$ далекою від нормативної завдяки своїм маркерам козацтва) не стала предметом загальної уваги, то запровадження фемінітивів викликало жваву дискусію та латентний супротив певного прошарку суспільства, зокрема, й мовознавців.

Підсумок дискусій щодо доцільності/недоцільності фемінітивізації мови, як і взагалі запровадження правопису в новій редакції, підвела Українська Національна Комісія з питань правопису на чолі з завідувачкою відділу стилістики, культури мови та соціолінгвістики Інституту української мови НАН України, член-кореспондента НАН України С.Я. Єрмоленко за участі провідних вчених Інституту української мови НАН України (В.В. Німчук， Н.Ф. Клименко， К.Г. Городенська) та професорів Київського національного університету імені Тараса Шевченка (О.Д. Пономарів, Л.П. Гнатюк).

Назагал, проблемою нового правопису, зокрема, творення та ужитку фемінітивів, а також суміжних $з$ нею проблем опікувалася плеяда відомих українських мовознавців, фонетистів, таких як А.М. Архангельська, А.Й. Багмут, О.С. Біла, М.П. Брус, Н.С. Вербич, І.С Гнатюк, К.Г. Городенська, П.Ю. Грице́нко, В.С. Калашник, Л.Б. Карпусь, О.А. Малахова, Л.Т. Масенко, В.М. Мойсієнко, I.M. Шпітько. Утім за усієї грунтовності їх досліджень, як на нас, варто висвітлити декотрі лінгвосоціальні аспекти проблеми реалізації нового правопису за сучасного стану мовної політики, зокрема, щодо ужитку фемінітивів. Відтак за мету нашої розвідки маємо висвітлення фемінітивізіції української мови у мовнокультурному та 
соціальному вимірах, обумовленість ужиткової форми фемінітивів фоносемантичним контекстом, суголоссям та артикуляційним виконанням.

\section{Матеріали та методи дослідження}

Джерельну базу дослідження становлять: щойно прийнятий новий правопис української мови, напрацювання Б.Д. Грінченка, I.I Огієнка, лексичний матеріал у літературних творах українських класиків, твори сучасних українських постмодерністів, а також словники фемінітивів.

За методи маємо порівняльно-історичний, метод дискурс-аналізу, дедукції, за логікою, що оцінка сьогодення криється у вивченні минулого.

За методологічну основу маємо соціолінгвістичні здобутки у працях О.О. Потебні, М.П. Драгоманова, синергетичну парадигму розвитку та самоорганізації мови на цивілізаційному перетині культур.

\section{Результати дослідження}

Загальновідомо, що мова є відбитком культури, політики, лакмусовим папірцем соціальної та гендерної політики. Українська мова як ніяка інша пережила складні часи свого становлення. На пам'ять спадають спроби принизити українську мову невизнанням ï як окремої, самодостатньої, як про це говорять Є.О. Болховитінов та М.Т. Каченовський. Останній українську мову визнавав «за сполонізоване наріччя польської мови». Але все ж таки гору взяв здоровий глузд та наукова виваженість, за якою українська мова визнана самостійною мовою в гурті слов'янських мов, як це обгрунтував відомий вчений, ректор Київського університету М.О. Максимович. Першим хто розпочав викладання в університеті українською мовою, був I.I. Огієнко. Він же стає й ініціатором та розробником українського правопису. Проте шлях до його остаточного запровадження був довгим та тернистим. Лише за дійсної незалежності українська мова зрештою отримала свій правопис. Але і сьогодні ще можна почути голоси не на користь української мови, зокрема, й у плані втілення у практику нового правопису.

За часів утвердження незалежності спроби змінити український правопис неодноразово зазнавали нападок з боку прихильників русифікованого іiі варіанту, завдяки чому мова стала предметом політичних маніпуляцій. Яскравим прикладом $\epsilon$ застосування ідеологічно заангажованими засобами масової інформації географічного - «на Україні» - задля позначення держави. Відтак форма «на Україні» зажила слави маркера українофобства. Фанаберія сучасних українофобів стала продовженням історичних традицій своїх великодержавних попередників, коли Україна мислилася як територія, а вираз «на Україні», відображав польський шовінізм. У мовно-культурному сьогоденні, коли українство утвердилося у власній незалежності, нарешті запанувала форма «в Україні». Вираз «на Україні», як це й має бути, набув синтаксичного унормування. Прийменник «на» 3 місцевим відмінком уживається в географічних позначеннях території «на Волині», «на Полтавщині», «на Мальдівах».

Упоравшись з однією ознакою політичної некоректності, мовознавці звернулися до іншої - звільнення української мови від невиправданого ужитку маскулінітивів. Втіленню нового правопису, як показала практика, передувала значна робота не лише мовознавців, а й культурологів, політологів, позаяк легітимізація нового правопису мови відбувається на перетині прогресивних та консервативних тенденцій, інтересів політиків, ідеологів, мовознавців. Зрештою після тривалих коливань українство утвердилося у думці щодо доцільності фемінітивізації мови як відображення нових цивілізаційних реалій, вияву національної ідентифікації, втраченої за часів русифікації усіх сфер культури. Поштовхом переходу на новий рівень національної ідентифікації стали соціально-політичні зрушення у новітній історії України, які й спричинили мовно-культурні флуктуації такого рівня, що мова як система перейшла на новий аттрактор у своєму розвитку, однією з домінант якого стала фемінітивізація мови 
“...Флуктации могут привести систему к направленным изменениям, к возникновению различных новых относительно устойчивых структур, а не просто к прежнему состоянию равновесия" (Князева, Курдюмов, 2002: 24). С підстави стверджувати, що на зміну стану невпорядкованості мови, яка обумовлена порушенням морфологосинтаксичних норм української мови (позначення жіночої статі чоловічими найменуваннями), уже необоротно прийшов інноваційний варіант синтаксичного унормування як новий стан рівноваги системи.

Показовим в цьому плані $є$ ужиток фемінітивів. Тож, щоб оцінити сучасний стан мовної культури, звернемося до ретроспекції фемінітивізації української мови.

За свідченням дослідників української мови, фемінітиви уперше згадувалися ще у церковнослов'янсько-українському друкованому словнику «Лексис» Лаврентія Зизанія у ХУІ столітті. Але 3 давніх часів і до сьогодні ужиток фемінітивів був тим лакмусовим папірцем, який ілюструє соціальний та гендерний стан суспільства. Ще в далекі дорадянські часи номінація жінки в просторіччі мала вибірковий характер. Фемінітиви окрім відображення своєрідності діалектного мовлення були ще й маркерами соціального стану жінки. За словами М.П. Брус, фемінітиви становили «розмовне згрубіле, фамільярне спілкування сільських жителів..., зневажливе ставлення до жінок як до посильної робочої сили, обтяженої й пригніченої безперервними господарськими турботами. Але це стосується жінок низької верстви населення, для позначення яких залучено досить багато номінацій із негативним забарвленням (льоха, любаска, мерза, наймичка, небога, повійниця, пиячка, помийниця, шельма). Натомість жінки вищої верстви населення (заможного стану, професійного статусу, чужого походження) іменовані переважно запозиченими словами (акушерка, бонна, властителька, лящка, навчителька, пані, панна, полька, франщузка). Навіть використання прізвищевих назв засвідчує відмінність між жінками різного стану: назви жінок за прізвищем, станом чоловіка позначають осіб високого стану (Вишневичева, баронова), а назви жінок за іменем чоловіка - осіб низького стану (Іваниха, Дмитриха). Отож найменування жінок, ... стали показниками розмежування осіб низького і високого соціального стану та водночас різного ставлення до них: згрубіло-зневажливого до перших (баба, стара, наймичка) і ввічливо-пошанного до других (їмость, добродійка, панночка» (Брус, 2019: 52-53).

Насиченою фемінітивами була й творчість творців української мовної культури П.О. Куліша, Т.Г. Шевченка. Згадаймо номінації жінок у їх творах як то: багатирка, сотниківна, гетьманша, докторша, королівна, диякониия, попівна, шинкарка, полковниия тощо.

Навіть після входження України до складу союзу, з перших радянських років і до середини тридцятих років в українській мові фемінітиви усе ще активно використовувалися. Варто згадати словники Б.Д. Грінченка, Д.І. Яворницького, насичені колоритними фемінітивами. Але опісля відомого рішення Раднаркому, під тиском політики русифікації мови, яка активно впроваджувалася на теренах України, фемінітиви стали зникати 3 обігу на догоду притаманним російській мові маскулінітивам, а ті, що залишилися в мовному обігу набули небажаного забарвлення Вважалося, що гендерній рівності більш пасує номінування обох статей маскулінітивами. Фемінітиви також застосовувалися, але зі значними обмеженнями i, як правило, у зневажливій формі. У радянських словниках навіть біля деяких номінацій професій фемінітивами ставилися позначки «розмовне» чи «зневажливе», що, власне, означало й принизливе ставлення до самих жінок. У державному документообігу, як правило, фемінітиви не використовувалися. Лише у художніх текстах та просторіччі та й то в обмеженому обсязі збереглися декотрі з них, утворені від іменників чоловічого роду суфіксами к(а), -ин(а), -ин(я), -ниц(я), -ес(а), на кшталт вчителька, лікарка, аптекарка, завідувачка, студентка, співачка, шахтарка, колгоспниця, учениця, робітниця, актриса, поетеса. У широкому ужитку панувала мова-служниця політики русифікації, відома своїми маскулінітивами у позначенні осіб обох статей. Наприклад, депутат, політик, соиіолог, професор, кандидат, посол та т.і. 
Але, усупереч задекларованій статевій рівності, не буде помилкою сказати, що позбавлення жінок власної номінації, підміна фемінітивів маскулінітивами $\epsilon$ відображенням справжньої дискримінації жінок у професії та й у суспільстві в цілому.

Назагал за радянських часів під гаслом інтернаціоналізації насправді втілювалася політика мовної русифікації усіх народів, а не тільки українського. Задекларована соціальна рівність, відсутність феміністичних рухів, i, головно, утвердження російської мови мовою міжнаціонального спілкування насправді становило політику, за якої узагалі відбувалося розчинення у поліетнічній категорії «историческая общность «советский народ» автентичність націй та народів різних мовних культур, віросповідань, i, як не дивно, таке становище не розбурхувало свідомість пересічних громадян та й більшості науковців. До розпаду Союзу українська мова знаходилася під пильною увагою політичних діячів від культури, і мало хто наважувався сказати, що позначення жіночої статі чоловічими найменуваннями суперечить морфолого-синтаксичним нормам української мови. Наприклад, у реченні «свою думку висловила доцент Іванченко» маємо сполучення іменника чоловічого роду із дієсловом у жіночому.

В офіційній мові у пошані були маскулінітиви, не дивлячись на очевидну їх дискримінаційність стосовно жінок. Не зважали й на те, що позначення статусу жінки чоловічим іменником спричиняло прагматичні незручності тим, що треба окремо зазначати стать особи. Скажімо, запис «кандидат наук, доцент Іванченко» не дає розуміння статі зазначеної особи.

Зрештою, за тридцять років розбудови національної держави українство згадало історію власної мови, змінивши правопис та, головно, запровадивши в обіг фемінітиви. Не останню роль у становлені нового правопису відіграла пам'ять про правописну систему I.I. Огієнка як взірець для розбудови сучасної мови.

Ужиток фемінітивів за щойно прийнятим новим правописом цілком виправданий не лише поверненням до автентичності української мови, а й показником гендеризації суспільства на зразок європейських демократій. Позначення осіб жіночої статі, як і має бути, іменниками жіночого роду назагал ще й становлять маркери рівності жінок та чоловіків бодай у мовному виразі. Фемінітиви за новим правописом бачаться проявом не лише шанобливого ставлення до історії власної мови, а й свідченням дійсного, а не декларованого пошанування жінки у суспільстві. Жінки на законодавчому рівні посіли чільне місце у владних інституціях та на професійних посадах, недоступних їм раніше. Відтак і виникла об'єктивна потреба відобразити їх рівність 3 чоловіками на мовному рівні фемінітивізацією. Тому сприяли як нова політика, так і соціальний прагматизм - скасування заборони на професії, які традиційно вважалися суто чоловічими, як, наприклад, військові професії. Як зазначає Г. Плачинда «посилюються громадські рухи в країні, у тому числі й за права жінок. Виник запит, є потреба часу - чітко артикулювати жінок у всіх суспільних процесах» (Плачинда, 2018).

Проте відома й інша позиція. Фемінітивізація мови наразі не набула однозначної оцінки як у пересічних громадян, так i в колі науковців. Одні відмову від маскулінітивів на користь фемінітивів тлумачать як заявку на відзначення статевих відмінностей, що зараз є не в пошані в цінностях європейських країн, на які орієнтується українська демократія. Інші, навпаки, тлумачать фемінізацію як прояв політики гендерної рівності, пошани до жінки. Соціологія ж свідчить на користь останніх. Показником домінування позитивного ставлення до фемінітивізації мови маємо зареєстрований у профільному комітеті Верховної Ради України за ініціативи народних обранців законопроект (№ 2450) «Про внесення змін до деяких законодавчих актів України щодо права фізичної особи на зміну по батькові», у разі прийняття якого як закону українці на кшталт європейських громадян матимуть право змінювати по батькові на по матері. Тож погодьмося, «використання фемінітивів у жодному разі не ображає та не принижує жінку, а навпаки, демонструє, що вона $є$ повноцінно суб'єктною у [суспільних] процесах. Що вона, зрештою, варта того, аби мати для себе 
в мові окрему назву, а не «заодно матися на увазі» (Плачинда, 2018), - пише авторка словника фемінітивів. Не можна відмовити авторці у правоті скзаного, якщо фемінітиви однаковою мірою позначають осіб незалежно від соціального статусу, як це наразі має місце, а не диференційовано, як це мало місце у давні часи, про що пише М.П. Брус (Брус, 2019: 52-53). Треба було пройти складний шлях дискусій, щоб зрештою на державному рівні втілити у практику документообігу та контенту засобів масової інформації новий/старий правопис, а разом і запровадити фемінітиви.

Українська мова велична у своєму різнобарв'ї, динаміці розвитку, густо насичена фразеологізмами, а тепер ще й фемінітивами. В одинадцятитомному словнику української мови (Білодід,1970-1980) налічується майже 800 іменниківфемінітивів. «Великий тлумачний словник сучасної української мови» (Бусел, 2005) містить близько 250 тисяч слів і словосполучень, проте навіть він наразі не відповідає новітнім мовнокультурним запитам. Щойно прийнятий новий правопис розкриває можливості безперешкодно поновити роботу над складанням нових словників задля задоволення потреб у позначенні нових професій, термінів тощо, породжених інформаційно-комунікативними технологіями. Тож на фахівців чекає величезна творча робота по впровадженню лексичних новацій у мову економіки, техніки, технологій та повсякдення.

Проте було б невиправданим оптимізмом говорити, що процес фімінітивізації мови відбувається безперешкодно. Як ми уже зазначали, не усі фемінітиви (як і сама ідея їх запровадження) знайшли свій позитивний відгук як у широких колах громадян, так і в журналістів та науковців. В утворенні фемінітивів наразі нічого не змінилося. Як і належить, вони утворюються суфіксами к(а), -ин(а), -ин(я), -ниц(я), -ес(а), але виникла пересторога щодо застосування уже відомих суфіксів задля утворення декотрих фемінітивів. Дещо незвично для частини українців звучать такі фемінітиви як гідеса, гінетикиня, дочентка, лавреатка, історикиня, канилерка, інженерка, другиня, редактриса, посолка, кравчиня, державниия, деканеса, фотографеса, педагогиня, творчиня політикиня, критикиня, екологиня та інші. Особлива настороженість щодо державної мовної політики у частині нового правопису виникає у пересічних мешканців, мовна культура яких формувалася під впливом східних сусідів. Втілюючи фемінітиви, варто зважати на соціальну пам'ять, виходячи із розуміння того, що мова $\epsilon$ оформленням думки, уяви про дійсність, таку, яка утвердилася у оцінках та цінностях людей.

Для покоління, обтяженого рудиментами русифікованої української мови, фемінітиви, принаймні частина 3 них, бачаться неологізмами якщо не оказіоналізмами. Проте не побутовий рівень несприйняття фемінітивів становить перепону їх втіленню у широкий обіг. Провідну роль у латентному супротиві втілення нового/старого правопису відіграють, як на нас, політичні та ідеологічні вподобання впливових кіл еліти. Якщо у пересічних громадян причиною несприйняття є соціальна пам'ять, ностальгічна компонента суспільної свідомості, то у еліти є більш глибокі причини. Проте, чи є зазначені причини нездоланними? Як на нас, ні. Адже відомо, що суспільна думка формується мільярди разів повтореною практикою. I те, що наразі видається неологізмом, згодом відіб'ється у мисленні нормативною лексикою, тобто відбудеться психологічна адаптація свідомості українців. Допомогти подолати інерційність, звичку мислити маскулінітивами $\epsilon$ першочерговим завданням, передусім, освітян та представників засобів масової інформації. А політична еліта не є якоюсь історичною константою, вона, як відомо, $є$ явищем тимчасовим, швидкоплинним, а назагал - конформістським.

А поки що, втративши із затвердженням нового правопису підгрунтя для офіційного опонування, ідеологічні супротивники фемінітивізації мови взяли на озброєння спекулятивний аргумент, кажучи, що позначення статевої приналежності не відповідає європейським гендерним нормам, немовби фемінітиви $є$ виявом соціальної нерівності статей. Нав'язується думка про недоцільність запровадження лексики, яка вказує на статеву приналежність особи, у той час, коли у європейських та й не тільки 
європейських цінностях демократії, на які ми орієнтуємося, панує гендерна політика, за якої розмиваються не лише соціальні, а й біологічні відмінності щодо статевої приналежності. Свропейський варіант гендера тягне за собою заборону навіть зазначення статі, а натомість визнання так званого третього роду.

Відтак, напрошується питання - чи узгоджується наразі українська мовна культура, зокрема, фемінітивізація із гендерною рівністю та багатовіковими християнськими традиціями українства? Так. А чи означають мовні інновації усунення будь-якого розрізнення за статевою ознакою за зразками європейського повного зречення статевих відмінностей? Звісно, ні, позаяк доведена до абсурду політика заборони позначення статевої приналежності стане руйнацією укладу життя українства, який формувався віками за канонами християнства. Важко уявити, що має повідомити акушерка замість традиційного - «У вас хлопчик!» чи «У вас дівчинка!». В Україні гендерна рівність імперативно закріплена на вищому рівні статтями Конституції і активно впроваджується в усіх сферах буття без впадання в крайнощі. Тож фемінітивізація мови не має виходити за рамки національних культурних традицій.

За раціонального підходу фемінітивізація мови не стане перешкодою на шляху до розвитку гендерної рівності у сферах влади, економіки, права, освіти. Номінування жіночої статі у фемінітивах, навпаки, лише закріплює соціальний статус жінки нарівні із чоловіком зі збереженням відмінностей на біологічному рівні. А спроби зіставлення наслідків українських мовних новацій із гендерними «здобутками» країн західної демократії є некоректним.

Не вдаючись у подробиці, відзначимо лише, що в європейських мовах також відзначається статева приналежність, бодай і дещо умовно. Наприклад, actor - actress, manager - manageress, Але $є$ і так званий common gender, який є спільним для позначення обох статей, скажімо, словом teacher позначається і вчитель, і вчителька. Ми не маємо наміру вдаватися у подробиці ужитку фемінітивів в інших мовах, відзначимо лише, що їх наявність аж ніяк не завадила запровадженню доволі розкріпаченої форми гендеризації у західноєвропейських країнах - аж до ступеня статевої тотожності. Гадаємо, фемінітивізація української мови не дійде до крайнощів - втілення в Україні неоціненних «здобутків» європейської цивілізації на кшталт санкціонування одностатевих сімей, свободи у виборі статі, скасування позначення «батько», «мати» тощо. Соціальна рівність визначається не лінгвістичними номінаціями, а моральним та інституціональним унормуванням демократичності суспільства у національних інтересах.

Утім фемінітивізація мови не має запроваджуватися беззастережно, свавільно номінуючи професії, нехтуючи як соціальними детермінантами, так і лінгвістичними нормами, такими чинниками як виконавча традиція, своєрідність фонетики (наскільки той чи інший фемінітив пасує загальній фонетичній системі мови), ритмомелодійність мови, специфіка артикуляції. Пам'ятаймо, що мовне виконання є не лише відбитком способу осягнення дійсності у мисленні, зрізом національної культури, а й виявом специфіки артикуляції окремого етносу. Скажімо, фемінітив «продавчиня»є не лише фонетично милозвучнішим, ніж русифікований «продавщиця», а й артикуляційно самобутнішим.

Назагал творенню та ужитку кожного фемінітиву має передувати його дослідження фахівцями 3 фоностилістики, ономасіології. Речення не $є$ простим набором окремих звуків; воно становить таку взаємообумовленість сполучуваності звуків, за якої артикуляція одного звуку певним чином корелюється 3 артикуляцію наступного. Тож формотворення фемінітивів контекстуально обумовлене фоносемантичними зв'язками, суголоссям суміжно розташованих слів. Наприклад, вибір між рівнозначними фемінітивами: фотографка, фотографиня, фотографеса або деканка, деканеса має відбуватися за сполучуваністю із попереднім та наступним словом (йдеться про формотворення, за якого один і той же онтологічний засновник відображається в різних формах, які різняться лише фонетично). 
Іншою засторогою від бездумного утворення фемінітивів $\epsilon$ омонімічність - можливий збіг різних за значенням, але однакових за звучанням слів. «Бувають також випадки, коли важко утворити фемінітиви або вже є іменник жіночого роду з іншим значенням. Наприклад, «пілот» - це людина, яка керує літаком, а от «пілотка» - це головний убір. Тому для номінації жінки за штурвалом літака вживають варіант «пілотеса» (Малахова, 2018).

У кожному окремому випадку визначення суфіксу задля утворення фемінітиву $є$ елементом творчості, але не свавілля. Не існує та й не може існувати єдиного підходу до утворення та ужитку фемінітивів. Тому зазначені сполучуваність суміжних звуків, їх артикуляційне виконання у мовленнєвому процесі мають стати приписом щодо доцільності/недоцільності застосування того чи іншого суфіксу утворення фемінітиву. Поміркованості у творенні фемінітивів вимагає і той факт, що у частини українців спостерігається прохолодність у ставленні до окремих фемінітивів. Підігрівають настрої софістичні спекуляції порівнянням позначення жіночим іменником статусу чоловіка, наприклад, голова (президії) із таким же позначенням жіночої статі іменником чоловічого роду (маскулінітивом). Тож на кожному етапі втілення у обіг мовних новацій мусимо, окрім дотримання лінгвістичних норм, виявляти ще толерантність щодо суспільної думки. Варто дослухатися до діалектики - крайнощі збігаються, тож благі наміри щодо номінації статей можуть спричинити зворотний ефект.

\section{Висновки та перспективи}

Таким чином, введення у обіг української мови широкого кола фемінітивів, безумовно, $є$ на часі як дієвий чинник національного самоутвердження українства у державній незалежності. Проте, фемінітивізація мови, як і будь-які інші мовні новації, досягає бажаного результату лише у разі їі поміркованості, не на шкоду національній злагоді. На жаль, аналіз декотрих коментарів щодо доцільності запровадження нового правопису засвідчив певну короткозорість, заангажованість самих коментаторів, їх здатність розрізняти лише два кольори - чорний та білий, що не на користь українству. Провідні ж вітчизняні лінгвісти, етнографи дійшли згоди, що реконструкція національної мови, широкий ужиток фемінітивів $\epsilon$ адекватною та необхідною відповіддю на новочасні суспільні запити. Тримаймо в полі зору, що «поки живе мова - житиме й народ як національність. Не стане мови - не стане й національності: вона геть роспорушиться поміж дужчим народом...» (Огієнко, 1918: 240), не русифікована мова і не мова постмодерністського зразка, а мова, виплекана душею народу попри усі утиски та кон'юнктурні забаганки.

Гадаємо, що тема щодо запровадження нового правопису не вичерпала себе. Бажана багатобарвність, толерантність в оцінках правописних новацій, як відомо, визріває у наукових дискусіях на засадах неупередженості, зацікавленості у результативності. Тож сподіваємося почути нові аргументи на користь утвердження українства у своїй мовно-культурній ідентичності у світлі Закону «Про забезпечення функціонування української мови як державної». Перспективним напрямком бачиться й дослідження словотворчого потенціалу суфіксів в фемінітивізації української мови.

\section{СПИСОК ВИКОРИСТАНИХ ДЖЕРЕЛ}

Білодід, 1970-1980 - Білодід. I.K. (ed.). Словник української мови: в 11 тт. АН УРСР. Інститут мовознавства. К.: Наукова думка, 1970-1980.

Брус, 2019 - Брус М.П. Словник фемінітивів як спроба упорядкування мови Леся Мартовича. Прикарпатський вісник НТШ. Слово. 2019. № 2(54). С. 50-61. DOI: $10.31471 / 2304-7402-2019-2(54)-50-61$

Брус, 2012 -Брус М. П.Фемінітивний світ художньої мови Леся Мартовича. Вісник Прикарпатського університету. Філологія. Івано-Франківськ: Вид-во Прикарпатського нац. ун-у ім. В. Стефаника. 2012. Вип. 34-35. С. 126-130. 
Бусел, 2005 - Бусел T.В.(ed.) Великий тлумачний словник сучасної української мови. К.: Ірпінь: ВТФ «Перун», 2005. 1728 с.

Клименко, 2008 -Клименко Н.Ф. Динамічні процеси в сучасному українському лексиконі: [монографія]. Київ: Вид. Дім Дмитра Бураго, 2008. 335 с.

Князева, Курдюмов, 2002 - Князева Е.Н., Курдюмов С.П. Основания синергетики. СПб.: Алетейя. 2002. 414 с.

Лишка, 2018 -Лишка Я. Фемінітиви в українській мові: запозичені неологізми, чи традиційні словотвірні форми? [Електронний ресурс] Режим доступу // http://report2018.tilda.ws/blogs/feminityvy

Малахова, 2018-Малахова O.A. Фемінітиви і як їх правильно утворювати. [Електронний ресурс] Режим доступу // http://pr.ua/news.php?new=50043

Німчук, 2004 - Німчук В.B. Переднє слово. До видання: Історія українського правопису: XVI - XX століття. Хрестоматія. Київ: Наукова думка, 2004. 584 c. [Електронний ресурс] Режим доступу // http://litopys.org.ua/rizne/nimch.htm

Огієнко, 1918 - Огієнко I. I. Українська культура. К.: І.Чоколов, 1918. 272 с.

Огієнко, 2004 - Огієнко I.I. Історія української літературної мови. Київ: Наша культура і наука. 2004. $434 \mathrm{c}$.

Плачинда, 2018 - Плачинда Г. Словничок фемінітивів для прес-офіцерів та пресофіцерок територіальних управлінь державної служби України 3 надзвичайних ситуацій. [Електронний ресурс] Режим доступу // http://www.wicc.net.ua/media/Slovnyk fem.pdf

Собецька, 2016 - Собецька Н.В. Вживання фемінітивів як прояв гендерної культури. Молодий вчений. 2016. № 12.1 (40). С. 375-378.

УП, 2019 - Український правопис. Схвалено Кабінетом Міністрів України (Постанова № 437 від 22 травня 2019 р.) [Електронний ресурс] Режим доступу // https://mon.gov.ua/storage/app/media/zagalna\%20serednya/\%202019.pdf

Шумлянський, 1921 -Шумлянський Ф.M. Найголовніші правила українського правопису: видання 1921 року Української академії наук. Херсон: Червоний селянин, 1921. 56 с. [Електронний ресурс] Режим доступу // http://korchiwjaka.blogspot.com/2013/02/1921.html

20 ННУП, 2019-20 найбільших новацій Українського правопису 2019 року. [Електронний ресурс] Режим доступу https://www.radiosvoboda.org/a/30025623.html

\section{REFERENCES}

Bilodid, 1970-1980 - Bilodid, I.K. (Ed.) (1970-1980). Slovnyk ukrainskoi movy: v 11 tt. [Ukrainian language Dictionary: in 11 vols.]. Kyiv. Naukova dumka [in Ukrainian]

Brus, 2019 - Brus M.P. (2019). Slovnyk feminityviv yak sproba uporiadkuvannia movy Lesia Martovycha. [Dictionary of Feminitives as an Attempt for Ordering a Language Lesia Martovycha]. Prykarpatskyi visnyk NTSh. Slovo. № 2(54), pp. 50-61 [in Ukrainian] DOI: 10.31471/2304-7402-2019-2(54)-50-61

Brus, 2012 -Brus M.P. (2012). Feminityvnyi svit khudozhnoi movy Lesia Martovycha. [The Feminine Field of Lesia Martovycha Artistic Language] Visnyk Prykarpatskoho universytetu. Filolohiia. Ivano-Frankivsk: Vyd-vo Prykarpatskoho nats. un-u im. V. Stefanyka. Vyp. 34-35. S. 126-130 [in Ukrainian]

Busel, 2005 -Busel T.V. (Ed.) (2005). Velykyi tlumachnyi slovnyk suchasnoi ukrainskoi movy. [The Ukrainian Language Great Explanatory Dictionary]. Kyiv, Irpin: VTF «Perun». 1728 p. [in Ukrainian]

Klymenko, 2008 - Klymenko N.F. (2008). Dynamichni protsesy v suchasnomu ukrainskomu leksykoni: [monohrafiia]. [Dynamic Activities in the Modern Ukrainian Lexicon: [monografia]]. Kyiv: Vyd. Dim Dmytra Buraho. 335 p. [in Ukrainian] 
Kniazeva, Kurdiumov, 2002 - Kniazeva E.N., $\quad$ Kurdiumov S.P. $\quad$ (2002). Osnovanija sinergetiki. [Foundations of Synergetics]. SPb.: Aleteiia. 414 p. [in Russian]

Lyshka, 2018 - Lyshka Ya. (2018). Feminityvy v ukrainskii movi: zapozycheni neolohizmy, chy tradytsiini slovotvirni formy? [Feminitives in Ukrainian: borrowed neologisms or traditional word-building forms?] Retrieved from: http://report2018.tilda.ws/blogs/feminityvy [in Ukrainian]

Malakhova, 2018 - Malakhova O.A. (2018). Feminityvy i yak yikh pravylno utvoriuvaty. [Feminitives and how to form it correctly]. Retrieved from: http://pr.ua/news.php?new=50043 [in Ukrainian]

Nimchuk, 2004 - Nimchuk V.V. (2004). Perednie slovo. Do vydannia: Istoriia ukrainskoho pravopysu: XVI - XX stolittia. Khrestomatiia. [To the publication: The History of the Ukrainian Orthography: XVI-XX centuries. Anthology]. Kyiv: Naukova dumka, 2004. 584 p. Retrieved from: http://litopys.org.ua/rizne/nimch.htm [in Ukrainian]

Ohiienko, 1918-Ohiienko I. I. (1918). Ukrainska kultura. [Culture of Ukraine]. K. I.Chokolov. 272 p. [in Ukrainian]

Ohiienko, 2004 - Ohiienko I.I. (2004). Istoriia ukrainskoi literaturnoi movy. [A History of Ukrainian Literary Language]. Kyiv: Nasha kultura i nauka. 434 p. [in Ukrainian]

Plachynda, 2018 - Plachynda H. (2018). Slovnychok feminityviv dlia pres-ofitseriv ta presofitserok terytorialnykh upravlin derzhavnoi sluzhby Ukrainy z nadzvychainykh sytuatsii. [The Feminitives dictionary for press officers and press officers of the local departments of the State Emergency Service of Ukraine]. Retrieved from: http://www.wicc.net.ua/media/Slovnyk fem.pdf [in Ukrainian]

Sobetska, 2016-Sobetska N.V. (2016). Vzhyvannia feminityviv yak proiav hendernoi kultury. [Using Feminitives as a sign of gender culture]. Molodyi vchenyi. № 12.1 (40), pp. 375-378. [in Ukrainian]

US, 2019 - Ukrainskyi pravopys. [Ukrainian Spelling]. (2019). Skhvaleno Kabinetom Ministriv Ukrainy (Postanova № 437 vid 22 travnia 2019 r.). Retrieved from: https://mon.gov.ua/storage/app/media/zagalna\%20serednya/\%202019.pdf [in Ukrainian]

Shumlianskyi, 1921 -Shumlianskyi F.M. (1921). Naiholovnishi pravyla ukrainskoho pravopysu: vydannia 1921 roku Ukrainskoi akademii nauk. [The Most Important Rules of Ukrainian Orthography: the 1921 publication of the Ukrainian Academy of Sciences]. Kherson: Chervonyi selianyn, 56 p. Retrieved from: http://korchiwjaka.blogspot.com/2013/02/1921.html [in Ukrainian]

20 NNUP, 2019 - 20 naibilshykh novatsii Ukrainskoho pravopysu 2019 roku. [Top 20 greatest Ukrainian orthography novations in 2019]. Retrieved from: https://www.radiosvoboda.org/a/30025623.html [in Ukrainian]

Received: 21 September, 2020 